\title{
Kualitas, Kemampuan Implantasi dan Viabilitas in-vivo Embrio Mencit (Mus muculus) Galur Swiss Webster Setelah Pembekuan Dengan Metode Vitrifikasi
}

\section{The Quality, Implantation Rate and in vivo Viability of the Swiss Webster Mouse Embryo After Vitrification}

\author{
Madihah $^{1}$, Hartanti Kusumaningtyas ${ }^{1}$, Arief Boediono ${ }^{2}$, Sony H. Sumarsono ${ }^{1 *}$ \\ ${ }^{1}$ Kelompok Keilmuan Fisiologi, Biologi Perkembangan dan Biomedika, Sekolah Ilmu dan Teknologi hayati, \\ Institut Teknologi Bandung, Jl Ganesha 10 Bandung 40132. \\ email: sonyheru@sith.itb.ac.id *Penulis untuk korespondensi \\ 2 Bagian Embriologi, Fakultas Kedokteran Hewan IPB, Kampus Darmaga-Bogor
}

\begin{abstract}
Reproductive technologies including in vitro fertilization (IVF), embryo manipulation, gamete and embryo freezing, thawing and embryo transfer were rapidly developed. Vitrification is an embryo freezing technique that is the most developed. In this experiment, we vitrified mouse embryos and then examined the embryos i.e: (i) the quality of the embryos after thawing, (ii) the implantation rate of the embryos and (iii) viability of the embryos in vivo. Morulae and blastocycsts were collected from female mice that were pregnant a day 3,5 . The embryos were equilibraten in $\mathrm{mPBS}+\mathbf{1 0 \%}$ etilene glycol. Vitrification was carried out by using $\mathrm{VAB}_{\mathrm{EDS}}$ medium, containing 6-10 embryos that were dropped into a tip of a straw, then frozen in liquid nitrogen for 24 hours. Thawing was carried out by flushing the embryos using mPBS suplemented with $0.5,0.25,0.1$ and $0 \mathrm{M}$ sucrose. After being incubated in $\mathrm{M} 2$ medium at $370 \mathrm{C}$ for 1-2 hours, the recovery embryos were then transferred into the uteri of day 2.5 of pseudopregnat females. The females were then sacrificed at day 16 of gestation and the total implantaion, total life and death fetuses, as well as resorpted embryos, were taken as data. The results showed that vitrification significantly $(\mathbf{p}<0,05)$ reduced the quality of the embryos, as well as their implantation rate and the viability of the fetuses, which may be caused by the unoptimal combination of the cryoprotectant in the vitrification medium, temperature and exposure time during vitrification.
\end{abstract}

Key words: embrio, mencit, vitrifikasi, etilen glikol, transfer embrio

Diterima: 12 Mei 2005, disetujui: 18 Oktober 2005

\section{Pendahuluan}

Rekayasa teknologi reproduksi berkembang dengan pesat selama tiga dekade terakhir. Teknik ini meliputi pengembangan fertilisasi in-vitro (FIV), manipulasi embrio, pembekuan gamet dan embrio, thawing dan transfer embrio. FIV bertujuan untuk mengatasi masalah infertilitas pada manusia dan memaksimalkan proses produksi peningkatan mutu hewan ternak. Teknik pembekuan gamet dan embrio digunakan untuk mengawetkan gamet atau embrio dalam jangka waktu yang tidak terbatas, sehingga memudahkan pengangkutan dan pemindahan dari satu lokasi ke lokasi lain yang jaraknya jauh tanpa mempengaruhi perkembangan embrio itu sendiri. Dengan demikian FIV dan teknologi reproduksi yang lain, misalnya teknologi pembekuan dan transfer embrio kepada induk resipien sangat penting untuk dikembangkan di masa yang akan datang karena menjadi faktor penting dalam rekayasa bioteknologi reproduksi. 
Teknik pembekuan embrio (kriopreservasi) dapat dibagi menjadi dua cara yaitu: (i) pembekuan secara perlahan-lahan (slow freezing). Pada teknik slow freezing digunakan krioprotektan dengan konsentrasi rendah dan dilakukan penurunan suhu secara perlahan-lahan dan terkontrol. Keuntungan teknik slow freezing adalah kerusakan sel karena tekanan osmotik yang tinggi dan toksisitas dari krioprotektan berkurang karena penurunan suhu secara bertahap. Kelemahan teknik slow freezing adalah terjadi pembentukan es intraseluler yang bersifat letal bagi sel embrio (Chi et al., 2002). (ii) Pembekuan secara cepat (quick freezing). Pada teknik quick freezing digunakan krioprotektan dengan konsentrasi lebih tinggi sehingga sel mengalami dehidrasi dan penurunan suhu dilakukan dengan cepat. Pada vitrifikasi secara quick freezing konsentrasi krioprotektan yang digunakan cukup tinggi sehingga pembentukan kristal es intraseluler pada proses pembekuan tidak terjadi. Akibat tingginya konsentrasi krioprotektan, timbul efek toksik yang bersifat letal bagi sel. Dengan demikian diperlukan suhu dan waktu papar yang optimum untuk meminimalisasi efek toksik dari krioprotektan terhadap sel (Rall \& Wood, 1994; Rusiyantono et al., 2000; Chi et al., 2002; Kasai et al., 2002). Pada saat dilakukan vitrifikasi, akan terjadi peningkatan viskositas sehingga cairan intraseluler akan mencapai suhu rendah dalam keadaan seperti kaca dan tidak mengalami kristalisasi (Özkavukcu and Erdemli, 2002).

Krioprotektan yang biasa digunakan untuk melindungi sel pada saat kriopreservasi adalah etilen glikol (EG). Krioprotektan EG diketahui memiliki efek toksik yang rendah terhadap embrio sapi tahap blastokista (Suzuki et al., 1993; Saha et al., 1994), embrio kambing tahap morula (Rusiyantono et al., 2000), dan embrio mencit tahap morula dan blastokista (Kasai et al., 2002). Selain itu dimetil sulfoksida (DMSO) juga digunakan sebagai krioprotektan untuk embrio mencit tahap dua sel, delapan sel dan morula karena dapat memelihara viabilitas embrio mencit secara in-vitro (Shaw and Trounson, 1989). Kombinasi EG dan DMSO merupakan krioprotektan intraseluler yang dapat melewati membran plasma karena memiliki berat molekul rendah (masing-masing 62,07 g/mol dan $73,18 \mathrm{~g} / \mathrm{mol}$ ) dan memiliki kemampuan melewati membran sel tinggi sehingga efektif untuk meminimalkan kerusakan sel akibat pembekuan yang disebabkan oleh meningkatnya konsentrasi elektrolit akibat eksosmosis air. Sedangkan sukrosa merupakan krioprotektan ekstraseluler yang memiliki berat molekul tinggi sehingga tidak dapat melewati membran plasma, namun dapat menginduksi pembentukan es ekstraseluler dan dapat mengurangi toksisitas krioprotektan intraseluler (Liu et al., 2000). Dalam penelitian ini medium $\mathrm{VAB}_{\mathrm{EDS}}$ digunakan untuk vitrifikasi embrio mencit. Embrio tersebut kemudian diuji kualitasnya pasca vitrifikasi yaitu meliputi: (i) perubahan morfologi, (ii) kemampuan implantasi intra uterus dan (iii) viabilitas embrio tersebut secara in-vivo.

\section{Metode Penelitian}

\section{Pengumpulan embrio mencit}

Mencit (Mus musculus) Swiss Webster betina di-superovulasi dengan menyuntikkan 5 IU PMSG (pregnant mare serum gonadotropin)/ekor secara intraperitoneal, diikuti dengan menyuntikkan 5 IU hCG (human chorionic gonadotropin)/ekor 48 jam kemudian. Mencit betina dikawinkan dengan mencit jantan normal semalam. Adanya sumbat vagina pada keesokan hari ditentukan sebagai UK 0 hari. Mencit betina didislokasi leher pada UK 3,5 hari kemudian dibedah. Uterus dan oviduct dikoleksi dalam cawan berisi mPBS (modified phosphate buffer saline) dan dengan menggunakan syrink $1 \mathrm{ml}$ medium disemprotkan ke dalam uterus. Embrio mencit tahap morula dan blastokista dikoleksi dengan mikropipet yang dikontrol dengan mulut dan dibagi menjadi dua kelompok yaitu: kelompok kontrol (embrio tanpa vitrifikasi) dan kelompok perlakuan (embrio divitrifikasi).

\section{Vitrifikasi embrio mencit}

Embrio kelompok perlakuan diekuilibrasi selama \pm 15 menit dalam larutan $\mathrm{mPBS}+10 \% \mathrm{EG}$, lalu divitrifikasi dalam medium $\mathrm{VAB}_{\text {EDS }}(15 \% \mathrm{EG}+15 \% \mathrm{DMSO}+$ $0,5 \mathrm{M}$ sukrosa dalam larutan mPBS) selama \pm 
1 menit pada suhu kamar $\left( \pm 27^{\circ} \mathrm{C}\right)$. Kemudian dengan pipet, medium $\operatorname{VAB}_{\mathrm{EDS}}( \pm 1 \mu \mathrm{L})$ yang berisi 6-10 embrio diteteskan pada ujung straw $0,25 \mathrm{~mL}$ yang dilancipkan. Ujung straw diuapi uap nitrogen cair selama 10 detik dan kemudian dimasukkan ke dalam nitrogen cair $\left(\mathrm{LN}_{2}\right)$. Straw berisi embrio disimpan dalam $\mathrm{LN}_{2}$ selama semalam. Embrio kelompok kontrol dipelihara dalam medium M2 pada suhu $37^{\circ} \mathrm{C}$ sampai ditransfer ke dalam uterus induk resipien.

\section{Thawing}

Straw yang berisi embrio dikeluarkan dari $\mathrm{LN}_{2}$ dan didiamkan dalam uap $\mathrm{LN}_{2}$ selama 10 detik, kemudian di-thawing pada suhu kamar $\left( \pm 27^{\circ} \mathrm{C}\right)$ secara bertahap, yaitu: pada larutan mPBS yang mengandung $0,5 \mathrm{M} ; 0,25$ $M$ dan 0,1 M sukrosa dengan total waktu selama lima menit untuk menghilangkan ekses krioprotektan. Embrio kemudian dipindah ke dalam medium mPBS beberapa kali dan terakhir ke dalam medium M2 diinkubasi pada suhu $37^{\circ} \mathrm{C}$ selama dua jam. Kualitas embrio hasil vitrifikasi dan thawing ditentukan dari keadaan morfologi setelah dikultur dan dicatat sebagai data.

\section{Transfer embrio pada induk resipien}

Induk resipien disiapkan dengan mengawinkan mencit betina dara umur delapan minggu dengan mencit jantan steril (divasektomi dan teruji steril) selama semalam. Adanya sumbat vagina pada keesokan paginya dikenali sebagai umur kebuntingan semu (UKS) 0 hari. Vasektomi dilakukan mengikuti Hogan et al., (1986) dan Sumarsono (1997).

Transfer embrio dilakukan mengikuti Hogan et al., (1986) dan Sumarsono et al., (1996). Induk resipien UKS 2,5 hari dibius dengan menyuntikkan $0,0012 \mathrm{mg} / \mathrm{ml}$ Avertin (Hogan et al, 1986) dan ditunggu hingga pingsan. Pada punggung mencit betina yang sudah pingsan dibuat sayatan pada kulit sejajar sumbu antrioposterior sepanjang $0,5 \mathrm{~cm}$. Sayatan kecil dibuat pada otot punggung tepat diatas ovarium yang tampak kemerahan. Badan lemak ditarik keluar sehingga saluran reproduksi ikut tertarik. Sebuah klem dipasang pada badan lemak sehingga uterus tetap berada di luar tubuh. Sebuah lubang dibuat pada uterus dengan menggunakan jarum 26G. Dengan menggunakan mikropipet, embrio hasil thawing dengan morfologi normal (enam embrio) ditransfer ke dalam uterus induk resipien sebelah kiri, sedangkan embrio kontrol (enam embrio) ditransfer ke dalam uterus sebelah kanan. Pada mencit betina resipien yang lain dilakukan secara sebaliknya, sehingga efek uterus kanan dan kiri dialami oleh kedua kelompok.

\section{Pengamatan kemampuan implantasi dan viabilitas embrio mencit in vivo}

Pada UK 16 hari induk resipien didislokasi leher dan dibedah. Penampilan reproduksi induk resipien diamati yaitu: (a) jumlah total implantasi, (b) jumlah fetus hidup, (c) jumlah fetus mati dan (d) jumlah embrio yang diresorpsi dan dicatat sebagai data. Data kemudian ditabulasi dan dilakukan analisis statistik dengan uji "t-student" untuk membuktikan adanya beda nyata antar kelompok pengamatan.

\section{Hasil Pembahasan}

\section{Kualitas embrio pasca vitrifikasi dan thawing}

Perubahan kualitas embrio mencit tahap morula dan blastokista setelah dilakukan vitrifiaksi dalam medium $\mathrm{VAB}_{\mathrm{EDS}}$, diikuti thawing dan pemeliharaan di dalam medium M2 selama 2 jam disajikan pada Tabel 1. Dari total 204 embrio yang divitrifikasi (100\%) hanya $174(85,3 \%)$ embrio yang dapat ditemukan kembali setelah vitrifikasi dan thawing. Sisanya, sebanyak $30(13,7 \%)$ embrio hilang dalam proses thawing. Kehilangan embrio terjadi pada tahap morula maupun blastokista, meskipun cukup sulit untuk menghitung secara pasti karena terjadi peningkatan jumlah embrio yang mengkerut (shrinking). Pasca thawing dan inkubasi di dalam medium M2 selama 2 jam kami temukan bahwa sebanyak $33,33 \%$ dari total populasi embrio yang berhasil ditemukan kembali tetap mengkerut dan tidak kembali ke bentuk normal. Sisanya, yaitu sebanyak $66,67 \%$ embrio mengalami recovery (kembali ke bentuk awal seperti sebelum vitrifikasi).

Biota Vol. XI (2), Juni 2006 
Embrio mencit tahap morula mengalami penurunan persentase jumlah embrio $(17,16 \%$ menjadi 12,07\%) yang tidak berbeda secara signifikan setelah vitrifikasi dan thawing ( $>0,05)$. Sedangkan embrio mencit tahap blastokista mengalami penurunan persentase jumlah embrio $(82,84 \%$ menjadi $54,60 \%)$ yang berbeda secara signifikan setelah vitrifikasi dan thawing $(\mathrm{p}<0,05)$. Gambar 1 menunjukkan embrio tahap morula dan blastula yang mengalami recovery dan yang tetap mengkerut (shringking) setelah vitrifikasi dan thawing.

Tabel 1. Persentase kualitas embrio mencit (Mus musculus) sebelum dan setelah vitrifikasi dan thawing

\begin{tabular}{|c|c|c|c|c|c|c|c|c|}
\hline \multirow[t]{2}{*}{ Kualitas embrio } & \multirow{2}{*}{$\begin{array}{c}\text { Jumlah } \\
\text { embrio } \\
(\%)\end{array}$} & \multicolumn{3}{|c|}{ Jumlah Morula (\%) } & \multicolumn{3}{|c|}{ Jumlah Blastokista (\%) } & \multirow{2}{*}{$\begin{array}{c}\text { Jumlah } \\
\text { Embrio } \\
\text { mengkerut } \\
\text { (shrinking) }\end{array}$} \\
\hline & & $\begin{array}{c}\text { Tidak } \\
\text { mampat }\end{array}$ & Mampat & Total & Awal & Lanjut & Total & \\
\hline Sebelum vitrifikasi & $\begin{array}{c}204 \\
(100)\end{array}$ & $\begin{array}{c}13 \\
(6,38)^{a}\end{array}$ & $\begin{array}{c}22 \\
(10,78)^{a}\end{array}$ & $35(17,16)^{\mathrm{a}}$ & $\begin{array}{c}102 \\
(50)^{\mathrm{a}}\end{array}$ & $\begin{array}{c}67 \\
(32,84)^{a}\end{array}$ & $\begin{array}{c}169 \\
(82,84)^{a}\end{array}$ & $\begin{array}{c}0 \\
(0)^{\mathrm{a}}\end{array}$ \\
\hline Setelah vitrifikasi & $\begin{array}{c}174 \\
(85,3)\end{array}$ & $\begin{array}{c}10 \\
(5,75)^{\mathrm{a}}\end{array}$ & $\begin{array}{c}11 \\
(6,32)^{\mathrm{a}}\end{array}$ & $21(12,07)^{\mathrm{a}}$ & $\begin{array}{c}58 \\
(33,33)^{a}\end{array}$ & $\begin{array}{c}37 \\
(21,27)^{b}\end{array}$ & $\begin{array}{c}95 \\
(54,60)^{b}\end{array}$ & $\begin{array}{c}58 \\
(33,33)^{b}\end{array}$ \\
\hline Embrio hilang & $\begin{array}{c}30 \\
(14,7) \\
\end{array}$ & - & - & - & - & - & - & - \\
\hline
\end{tabular}

Keterangan:

Diuji dengan uji " $t$-student"

Huruf yang berbeda dalam satu kolom menunjukkan perbedaan yang signifikan $(\mathrm{p}<0,05)$

Kualitas embrio pasca transfer embrio ke dalam uterus induk resipien

Kemampuan implantasi dan viabilitas embrio mencit secara in-vivo diuji dengan melakukan transfer embrio ke dalam uterus induk resipien. Pada penelitian ini, hanya embrio mencit tahap morula dan blastokista yang memiliki morfologi normal seperti sebelum vitrifikasi dan thawing saja yang ditransfer ke dalam uterus induk resipien. Pengamatan dilakukan setelah induk resipien bunting 16 hari. Induk didislokasi leher dan dibedah. Jumlah embrio implantasi, jumlah fetus hidup, jumlah fetus mati dan jumlah resorpsi embrio dihitung. Hasil pengamatan tersebut disajikan pada Tabel 2. Dari Tabel 2 tampak adanya penurunan kemampuan implantasi dan viabilitas secara in-vivo dari embrio mencit tahap morula dan blastokista divitrifikasi dan thawing. Akibat perlakuan vitrifikasi dan thawing persentase keberhasilan implantasi dari embrio mencit mengalami penurunan hingga 38,79\% lebih rendah secara signifikan dibandingkan dengan kemampuan implantasi embrio kelompok kontrol yang mencapai 48,36\% $(\mathrm{p}<0,05)$.

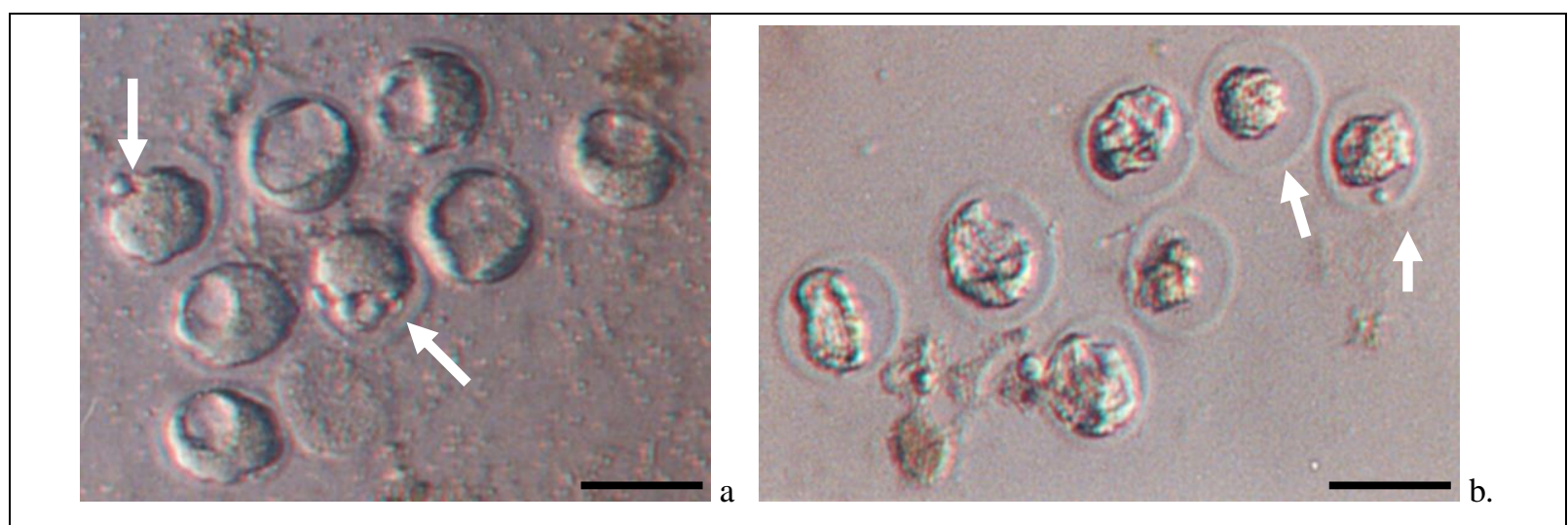

Gambar 1. Morfologi embrio mencit setelah vitrifikasi-thawing: (a) embrio mencit tahap morula (tanda panah) dan blastokista (tanpa tanda panah) yang dapat kembali ke bentuk normal (recovery) setelah dilakukan vitrifikasi dan thawing, (b) embrio mencit tahap morula (panah) dan blastokista (tanpa tanda panah) yang mengkerut dan rusak setelah proses vitrifikasi dan thawing $(=150 \mu \mathrm{m}$ ). 
Viabilitas in-vivo embrio mencit yang ditransfer ditunjukkan oleh jumlah fetus hidup. Jumlah fetus hidup juga menunjukkan tingkat keberhasilan hidup embrio yang ditransfer dan keberhasilan hidup embrio yang terimplantasi. Dari hasil penelitian ini tampak bahwa vitrifikasi dalam medium $\mathrm{VAB}_{\mathrm{EDS}}$ menghasilkan penurunan yang signifikan dari persentase rata-rata keberhasilan hidup embrio yang ditransfer mencapai 30,17\% (35/116) dibandingkan dengan embrio kontrol yang mencapai $38,52 \% \quad(\mathrm{p}<0,05)$. Sedangkan persentase rata-rata keberhasilan hidup embrio yang terimplantasi $77,78 \%$ (35/45) berbeda secara signifikan dibandingkan dengan kontrol yang mencapai $79,66 \%(\mathrm{p}<0,05)$. Persentase rata-rata embrio terimplantasi yang mengalami kematian intrauterus (embrio yang diresorpsi dan fetus yang mati) mencapai $22,22 \%$ dari embrio mencit tahap morula dan blastokista yang divitrifikasi dalam medium $\mathrm{VAB}_{\mathrm{EDS}}$ menunjukkan peningkatan yang tidak signifikan terhadap kontrol yang mencapai 20,34\%. Dari hasil penelitian ini tampak bahwa vitrifikasi tidak mempengaruhi kualitas embrio pasca-implantasi yang ditunjukkan oleh jumlah embrio yang diresorpsi dan jumlah fetus yang mengalami kematian intrauterus. Rata-rata berat fetus yang berkembang dari embrio mencit tahap morula dan blastokista yang divitrifikasi dalam medium $\operatorname{VAB}_{\mathrm{EDS}}(0,64 \pm$ 0,21 g) mengalami penurunan yang tidak signifikan dibandingkan dengan kontrol $(0,67$ $\pm 0,23 \mathrm{~g})$. Dari hasil tersebut tampak bahwa vitrifikasi tidak mempengaruhi perkembangan embrio pasca-implantasi sehingga embrio dapat berkembang menjadi fetus normal.

Tabel 2. Efektivitas metode vitrifikasi terhadap kemampuan implantasi dan viabilitas in-vivo embrio mencit (Mus musculus) setelah ditransfer ke induk resipien bunting semu

\begin{tabular}{|c|c|c|}
\hline & $\begin{array}{c}\text { Kontrol } \\
\text { (embrio tanpa vitrifikasi) }\end{array}$ & $\begin{array}{c}\text { Perlakuan } \\
\text { (embrio dengan vitrifikasi) }\end{array}$ \\
\hline Jumlah induk resipien (ekor) & 10 & 10 \\
\hline Jumlah embrio yang ditransfer & 122 & 116 \\
\hline $\begin{array}{l}\text { Persentase rata-rata keberhasilan implantasi } \\
\text { (jumlah implantasi) }\end{array}$ & $\begin{array}{l}48,36 \% \\
\quad(59)\end{array}$ & $\begin{array}{l}38,79 \% * \\
\quad(45)\end{array}$ \\
\hline Persentase rata-rata keberhasilan hidup embrio & $38,52 \%$ & $30,17 \% *$ \\
\hline yang ditransfer (jumlah fetus hidup) & (47) & (35) \\
\hline Persentase rata-rata keberhasilan hidup embrio & $79,66 \%$ & $77,78 \% *$ \\
\hline yang terimplantasi (jumlah fetus hidup) & $(47)$ & $(35)$ \\
\hline Persentase rata-rata embrio terimplantasi yang & $20,34 \%$ & $22,22 \%{ }^{\text {ts }}$ \\
\hline mengalami kematian intrauterus (jumlah) & (12) & (10) \\
\hline Rata-rata berat badan fetus $(X \pm S D g)$ & $0,67 \pm 0,23$ & $0,64 \pm 0,21^{\text {ts }}$ \\
\hline
\end{tabular}

\section{Diskusi}

Hasil penelitian menunjukkan adanya penurunan kualitas embrio setelah vitrifikasi dan thawing hingga mencapai 33,33\%. Penurunan kualitas embrio ini cukup tinggi dibandingkan dengan peneltian Lopatáŕová et al. (2002) pada embrio sapi. Dengan menggunakan medium yang ditambah $16,5 \%$ $\mathrm{EG}+16,5 \% \mathrm{DMSO}+0,5 \mathrm{M}$ sukrosa, Lopatarova et al. (2002) menunjukkan tingkat recovery yang tinggi yaitu sekitar 92,9\% untuk embrio sapi yang digunakan. Dalam percobaan tersebut Lopatarova et al. (2002) menggunakan waktu inkubasi lebih lama yaitu 72 jam, dibandingkan dengan waktu yang kami gunakan dalam penelitian ini (24 jam).

Pada saat embrio dipaparkan pada medium vitrifikasi, air akan mengalami eksosmosis dan sejumlah tertentu etilen glikol (EG) dan dimetil sulfoksida (DMSO) akan masuk ke dalam sel-sel embrio. Pada saat yang sama sukrosa akan membantu terjadinya dehidrasi sel, akibatnya sel akan mengkerut (Saha et al., 1994). Pada saat dilakukan thawing embrio dipaparkan secara bertahap pada beberapa medium hipertonik mengandung sukrosa. Medium hipertonik ini dapat Biota Vol. XI (2), Juni 2006 
mencegah influks air yang sangat cepat masuk ke dalam sel. Pada saat yang bersamaan EG dan DMSO akan keluar dari sel sehingga menurunkan gradien konsentrasi antara intraseluler dan ekstraseluler. Aliran EG dan DMSO ini dapat menghentikan pergerakan air melewati membran sel, sehingga mencegah lisis sel pada saat terjadi difusi EG dan DMSO ke luar (Özkavukcu and Erdemli, 2002). Embrio mengembang kembali karena air masuk ke dalam sel dan sel akan kembali ke ukuran normal setelah embrio dikultur selama 1-2 jam di dalam medium M2. Embrio yang tetap mengkerut setelah vitrifikasi dan thawing disebabkan oleh embrio tidak berhasil kembali ke kondisi semula, disebabkan adanya perubahan tekanan osmotik yang besar pada saat vitrifikasi dan thawing. Peruabahn tekanan osmotik yang besar akan meningkatkan konsentrasi ion intraseluler, dan menyebabkan kerusakan membran plasma dan mengurangi permeabilitas sel embrio yang berakibat sel embrio gagal mengembang (Lopatáŕová et al., 2002).

Selain itu dalam penelitian ini juga terdapat sejumlah embrio yang hilang pada saat thawing (sekitar 14,7\%). Kehilangan embrio pada penelitian ini tidak berbeda dengan hasil penelitian yang dilakukan oleh Pantano et al. (2000) yang menunjukkan embrio yang hilang pada saat thawing mencapai $1,7 \%$ sampai $13,3 \%$. Kehilangan embrio bisa disebabkan oleh embrio yang menempel/lengket pada dinding straw sehingga sulit dilepaskan pada saat thawing. Secara teoritis kehilangan embrio karena lengket pada dinding straw bisa diminimalkan dengan mengamati straw dibawah mikroskop untuk mengecek apabila masih ada embrio yang menempel. Pembilasan ulang dengan larutan mPBS+0,5 M sukrosa bisa dilakukan untuk melepas embrio yang masih menempel, meskipun belum tentu embrio yang lengket bisa lepas dari dinding straw. Pemaksaan pelepasan secara fisik bisa berakibat rusaknya embrio. Kehilangan embrio juga bisa terjadi pada proses vitrifikasi, yaitu ketika straw dimasukkan ke dalam nitrogen cair tetesan medium yang berisi embrio lepas dari dinding straw. Meskipun demikian secara umum medium yang berisi embrio pada ujung straw akan membeku dengan cepat begitu Biota Vol. XI (2), Juni 2006 terkena uap nitrogen cair karena suhu uap nitrogen yang sangat rendah. Dari hasil ini dapat diketahui bahwa metode vitrifikasi dengan menggunakan medium $\mathrm{VAB}_{\mathrm{EDS}}$ yang diteteskan pada ujung straw yang dilancipkan tanpai ditutup dapat digunakan. Teknik straw lancip ini berbeda dengan banyak teknik pembekuan yang digunakan terdahulu dimana digunakan medium dalam jumlah cukup banyak dalam straw yang ujungnya ditutup/diklem.

Penurunan kemampuan implantasi dari embrio mencit tahap morula dan blastokista pada percobaan ini mungkin disebabkan oleh adanya kerusakan sel-sel embrio akibat penggunaan krioprotektan dengan konsentrasi tinggi, walaupun kerusakan sel tersebut tidak tampak secara morfologi setelah embrio dikultur pada medium M2 selama satu sampai dengan dua jam pada suhu $37^{\circ} \mathrm{C}$. Menurut Kasai et al. (2002) kerusakan sel-sel embrio akibat vitrifikasi dapat diidentifikasi dari keadaan morfologinya setelah embrio hasil thawing dikultur dalam medium kultur selama satu sampai dengan 24 jam. Meskipun demikian kerusakan struktur sel tanpa ditandai kerusakan membran sel mungkin sangat sulit diidentifikasi dari morfologi sel-sel blastomer itu sendiri. Kerusakan struktur internal sel blastomer bisa menyebabkan kematian sel pada tahap selanjutnya. Apabila terjadi kematian sel, maka dapat menyebabkan kematian embrio secara keseluruhan. Kematian sel blastomer akan berpengaruh sangat besar terhadap kemampuan implantasi embrio. Selain itu, menurut de Mello et al. (2001) adanya pengurangan jumlah blastomer atau kerusakan pada blastomer pada saat dibekukan dapat menyebabkan terjadinya kematian fetus intrauterus.

Pelaksanaan transfer embrio membutuhkan keterampilan dari peneliti sehingga sejalan dengan meningkatnya keterampilan peneliti dalam melakukan transfer embrio, diharapkan keberhasilan implantasi akan meningkat pula (de Mello et al., 2001). Keberhasilan transfer embrio dipengaruhi oleh beberapa faktor, seperti: galur mencit yang digunakan, tahap embrio yang ditransfer, kualitas dan kuantitas embrio yang ditransfer, kemampuan uterus induk resipien untuk 
menerima implantasi, sinkronisasi embrio donor dengan umur kebuntingan semu induk resipien, kondisi lingkungan pemeliharaan dan penyediaan mencit jantan yang benar-benar mandul (Hogan et al., 1986; Sumarsono, 1997). Percobaan transfer sebelumnya menunjukkan bahwa dengan menggunakan mencit galur F1 (Balb/c X C57) dicapai tingkat keberhasilan implantasi hingga $72,5 \%$, sedangkan dengan menggunakan Swiss Webster bisa dicapai keberhasilan implantasi antara 62,5\% (Sumarsono, 1997; Sumarsono et al., 2001a,b; Sumarsono et al., 2002). Pada penelitian ini embrio yang mengalai implantasi sebesar $48,36 \%$ (kelompok kontrol) dan 38,79\% (kelompok perlakuan), jauh dibawah kondisi yang telah dilaporkan Sumarsono (Sumarsono, 1997; Sumarsono et al., 2001a,b; Sumarsono et al., 2002).

Penurunan viabilitas in-vivo kemungkinan disebabkan oleh terjadinya penurunan kualitas embrio mencit, terutama embrio tahap blastokista yang digunakan. Menurut Rall and Wood (1994) embrio mencit tahap blastokista lebih rawan terhadap pembekuan karena adanya dinamika cairan di dalam rongga blastokista (blastosol) sehingga kemungkinan terbentuknya kristal es menjadi lebih besar dan dapat menyebabkan kerusakan embrio. Pada penelitian ini jumlah embrio tahap blastokista yang digunakan lebih banyak daripada embrio tahap morula. Meskipun embrio tahap yang divitrifikasi telah kembali ke bentuk normal setelah thawing dan inkubasi, kerusakan blastomer pada blastokista kemungkinan menyebabkan terjadinya penurunan viabilitas in-vivo secara keseluruhan menjadi signifikan. Selain itu penurunan viabilitas secara in-vivo dari embrio mencit tahap morula dan blastokista bisa disebabkan oleh kombinasi konsentrasi krioprotektan yang kurang tepat, suhu papar dan lamanya waktu papar terhadap krioprotektan yang digunakan untuk mencegah terjadinya kerusakan sel-sel embrio sehingga menurunkan tingkat kelulushidupan dari embrio mencit. Untuk mendapatkan kombinasi konsentrasi krioprotektan, suhu papar dan lamanya waktu papar yang optimum untuk meminimalkan efek toksik dari krioprotektan sehingga dapat melindungi sel-sel embrio pada saat dibekukan diperlukan percobaan lebih lanjut. Hasil penelitian El-Gayar and Holtz (2001) yang menggunakan medium vitrifikasi mengandung $20 \%$ EG dan 20\% DMSO yang dipaparkan pada suhu $39^{\circ} \mathrm{C}$ selama 20 detik menunjukkan viabilitas in-vitro dan in-vivo yang tinggi dari embrio kambing yang digunakan dan jumlah fetus hidup mencapai 64\%. Hal lain yang mungkin menyebabkan penurunan kualitas embrio pasca vitrifikasi dan thawing adalah penggunaan sukrosa yang kurang efektif dibandingkan dengan trehalosa dalam mengurangi kerusakan sel akibat pembekuan (Bagis et al., 2002).

Dari semua diskusi di atas kami berkesimpulan bahwa vitrifikasi embrio mencit tahap morula dan blastokista dengan menggunakan medium $\mathrm{VAB}_{\mathrm{EDS}}(15 \% \mathrm{EG}, 15 \%$ DMSO dan 0,5 $\mathrm{M}$ sukrosa) yang dipaparkan pada suhu kamar $\left( \pm 27^{\circ} \mathrm{C}\right)$ selama \pm 1 menit terbukti dapat dilakukan dengan sukses. Teknologi ini dapat digunakan untuk mendukung program teknologi reproduksi dengan atau tanpa rekayasa pada embrio. Teknologi reproduksi berupa vitrifikasi embrio, thawing dan embrio transfer sangat diperlukan dalam mengatasi kasus infertilitas pada manusia. Embrio hasil fertilisasi secara in vitro (IVF) perlu disimpan beku terlebih dahulu apabila calon ibu yang akan mengandung embrio tersebut belum siap untuk dilakukan transfer embrio. Embrio ditrasnfer jika calon ibu kandung (surogate mother/resipen) dalam kondisi uterus siap untuk impnlantasi sehingga kehamilan bis diperoleh. Dimasa depan teknologi vitrifikasi (pembekuan) embrio, thawing dan transfer embrio dapat dikembangkan untuk menyimpan sel-sel gamet (sperma dan sel telur) maupun embrio hewan mamalia langka seperti kucing hutan, harimau, badak jawa, badak sumatra, rusa dan kancil yang jumlah populsinya semakin kecil karena rusaknya habitat dan keggalan reproduksi alami. Meskipun demikian perlu pula dicatat bahwa teknologi pembekuan dan penyimpanan embrio ini juga menyimpan potensi adanya penurunan kualitas embrio pasca-thawing, penurunan kemampuan implantasi dan penuruan viabilitas embrio secara in-vivo, miskupun tidak mempengaruhi viabilitas dan perkembangan embrio pasca-implantasi.

Biota Vol. XI (1), Februari 2006 


\section{Ucapan Terima Kasih}

Penelitian ini terlaksana berkat dukungan secara sebagian dari dana Riset Unggulan Terpadu IX tahun 2003.

\section{Daftar Pustaka}

Bagis, H., Sagirkaya, H. and Dinnyés, A. 2002. Vitrification of pronuclear stage mouse embryos in microdrops vs. cryotubes and the effects of the sugar content of the vitrification solution. Theriogenology. 57 (1): 461.

Chi, H.J., Koo, J.J., Kim, M.Y., Joo, J.Y., Chang, S.S. and Chung, K.S. 2002. Cryopreservation of human embryos using ethylene glycol in controlled slow freezing. Human Reproduction. 17 (8): 2146-2151.

Cseh, S., Wang, G., Corselli, J., Nehlsen-Cannarella, S.L., Bailey, L.L. and Szalay, A.A. 1996. Rapid freezing of mouse embryos in ethylene glycol at different preimplantation stages. Acta Vet. Hung. 44 (4): 457-465.

de Mello, M.R.B., Queiroz, V.S., de Lima, A.S., Tavares, L.M.T., Assumpção, M.E.O.D., Wheeler, M.B. and Visintin, T.A. 2001. Cryopreservation of mouse morulae through different methods: slow-freezing, vitrification and quick-freezing. 2001. Braz. J. Vet. Anim. Sci. 38 (4): 160-164.

El-Gayar, M. and Holtz, W. 2001. Technical note: vitrification of goat embryos by open pulledstraw method. J. Anim. Sci. 79: 2436-2438. (tidak diacu dalam naskah)

Hogan, B., Contantini, F. and Lacy, E. 1986. Manipulating the mouse embryo: a laboratory manual. Cold Spring Harbor Laboratory, New York.

Kasai, M., Ito, K. and Edashige, K. 2002. Morphological appearance of the cryopreserved mouse blastocyst as a tool to identify the type of cryoinjury. Human Reproduction. 17 (7): 1863-1874.

Liu, J., Woods, E.J., Agca, Y., Critser, E.S. and Critser, J.K. 2000. Cryobiology of rat embryos II: a theoretical model for the development of interrupted slow freezing procedures. Biology of Reproduction. 63: 1303-1312.

Lopatáŕová, M., Ćech, S., Havlíček, V. and Holy, L. 2002. Effect of vitrification in open pulled straws on survival of bovine embryo from superovulated cows. Acta Vet. Bmo. 71: 9399.

Özkavukcu, S. and Erdemli, E. 2002. Cryopreservation: basic knowledge and biophysical effects. Journal of Ankara Medical School. 24 (4): $187-196$

Biota Vol. XI (2), Juni 2006
Pantano, T., de Mello, M.R.B., Garcia, J.F. Ho, L.L. and Visintin, J.A. 2000. Effects of cryoprotectant and plunging temperature in liquid nitrogen on the in vitro and in vivo development of murine morulae. Braz. J Vet. Res. Anim. Sci. $37 \quad$ (3): 00-00 http://www.scielo.br/scielo.php?script=sci_ar ttext\&pid=S1413-95962000000300012

Rall, W.F. and Wood, M.J. 1994. High In vitro and in vivo survival of day 3 maouse embryos vitrified or frozen in a non-toxic solution of glycerol and albumin. J. Reprod Fertil. 101(3):681-688

Rusiyantono, Y., Boediono, A., Sukra, Y., Toelihere, M.R., Supriyatna, I. dan Purwantara, B. 2000. Pemakaian etilen glikol untuk vitrifikasi embrio kambing in-vitro. Prosiding Seminar Nasional Bioteknologi Pertanian. pp:47-51.

Saha, S., Takagi, M., Boediono, A. and Suzuki, T. 1994. Direct rehydration of in-vitro fertilized bovine embryos after vitrification. Veterinary record. 134: 276-277.

Shaw, J.M. and Trounson, A.O. 1989. Effect of dimethyl sulfoxide and protein concentration on the viability of two-cell mouse embryos frozen with a rapid freezing technique. Cryobiology. 26: 413-421.

Sumarsono, S.H. 1997. Pengembangan teknologi transfer embrio mencit (Mus musculus) dengan kondisi laboratorium di ITB. Laporan Penelitian OPF-ITB tahun 1996/1997, ITB.

Sumarsono, S.H., Adelina, M. dan Kusumaningtyas, H. 2001a. Asam Metoksiasetat terbukti menurunkan kualitas embrio Mencit Swiss Webster tahap praimplantasi. Hayati 8(3): 62-65.

Sumarsono, S.H., Sudarwati, S. dan Kaiin E.M. 2001b. Asam Metoksiasetat (MAA) menurunkan kualitas dan kemampuan implantasi embrio mencit Swiss Webster langsung maupun tidak langsung. Prosiding Seminar MIPA 2000. Fakultas Matematika dan Ilmu Pengetahuan Alam, Institut Teknologi Bandung.

Sumarsono, S.H., Ibrahim, M. dan Sudarwati, S. 2002. The effect of methoxyacetic acid (MAA) and MAA-treated internal uterine environtment on the quality of Swiss Webster mouse preimplantation embryo and their viability on postimplantation stage. Reprotech 2: 97-101.

Suzuki, T., Takagi, M., Yamamoto, M., Boediono, A., Saha, S., Sakakibara, H. and Oe, M. 1993. Pregnancy rate and survival in culture of invitro fertilized bovine embryos frozen in various cryoprotectants and thawed using a one-step system.Theriogenelogy. 40:651-659. 